\title{
A NOVEL METABOLITE FROM THE CHILEAN MOLLUSK Siphonaria lessoni
}

\author{
Juana Rovirosa and Aurelio San-Martín* \\ Departamento de Química, Facultad de Ciencias, Universidad de Chile, Casilla 653, Santiago, Chile
}

Recebido em 12/11/04; aceito em 29/4/05; publicado na web em 3/10/05

\begin{abstract}
A new and two previously known metabolites possessing a polypropionate carbon skeleton have been isolated from the marine gastropod mollusk Siphonaria lessoni, collected at Chilean coasts. Their structures have been determined by spectroscopical methods.
\end{abstract}

Keywords: mollusk; Siphonaria; polypropionates.

\section{INTRODUCTION}

Mollusks of the marine pulmonate genus Siphonaria are air breathing intertidal herbivores, often referred to as false limpets. During the high tides, siphonariids remain firmly fixed to depressions or "home scars" in the rock surface. As the tide recedes these mollusks leave their home scars to feed on algae and microorganisms thus exposing themselves to predation by terrestrial predators, in addition to the aquatic predators e.g. tidepool fish encountered when they are submerged. Shortly after being disturbed by a potential predator, siphonariids produce a white mucus, containing polypropionate metabolites, from lateral pedal glands ${ }^{1}$. A feature of Siphonaria polypropionate compounds is their frequent cyclization to yield furanone, pyrone and hemi-acetal functionalities ${ }^{2}$. Surprisingly, the role of these compounds in the chemical ecology of Siphonaria species is poorly understood ${ }^{2}$.

Siphonariid limpets have been shown to contain branched chain plypropionate metabolites of considerable biosynthetic interest ${ }^{3}$. For example, the air - breathing gastropod $S$. diemenensis contains the diemenensins $\mathrm{A}$ and $\mathrm{B}$, compounds that display antimicrobial properties ${ }^{4}$. On the other hand, the pulmonate $S$. denticulata Quay and Gaimard biosynthesizes the denticulatins $\mathrm{A}$ and $\mathrm{B}$, polypropionate compounds that have attracted considerable attention from both synthetic and bioorganic chemists ${ }^{5-7}$. Chilean specimens of S. lessoni yielded norpectinatone $\underline{1}$, norsiphonarianone $\underline{2}$, norsiphonarienolone ${ }^{8} \underline{3}$ and a mixture of furanone $\underline{4}$ and other isomer ${ }^{9}$. The nature of this isomer is no clear because originally was suggested that is the $\mathrm{Z}$ - isomer but further it was assigned to the epimer of carbon 2. In addition, norsiphonarianone and norsiphonarienolone were found as a mixture. The isolation of mixture of polypropionates in these mollusks is not an unusual situation ${ }^{10}$.

Over the last thirty years, many structurally novel polypropionate metabolites have been isolated from marine organisms as phylogenetically diverse as marine bacteria and sponges. The most important source of marine polypropionate compounds are the Mollusca.

In continuation of our search for new bioactive compounds from Chilean marine mollusks, we have reexamined specimens of $S$. lessoni from the central coast of Chile.

*e-mail: aurelio@uchile.cl

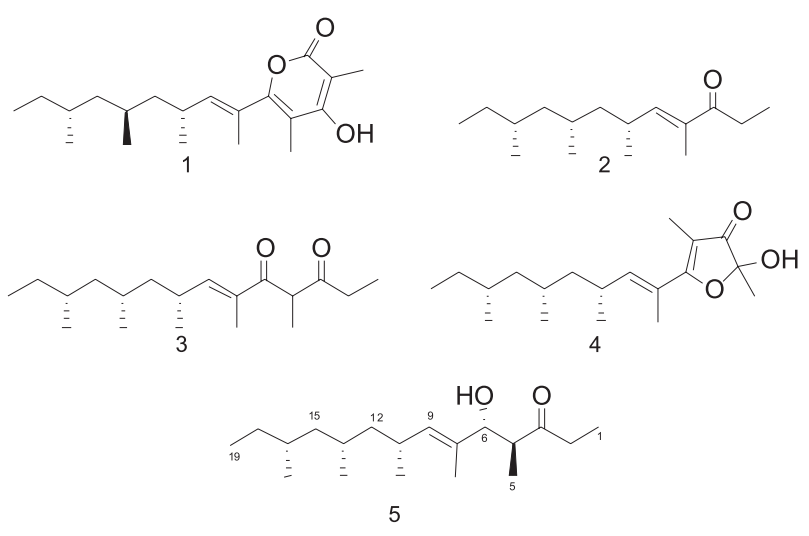

RESULTS AND DISCUSSION

The acetone extract of S. lessoni was subjected to open column chromatography on silica gel, using increasing proportions of ethyl acetate in petrol ether to afford a new polypropionate $\underline{5}$ and the mixtures of the known compounds $\underline{3}$ and $\underline{4}$. The IR spectrum of compound $\underline{5}$ presented bands at 3460 and $1700 \mathrm{~cm}^{-1}$ indicating the presence of an hydroxyl and carbonyl groups. The ${ }^{13} \mathrm{C}-\mathrm{NMR}$ spectral data (see table 1 ) of $\underline{5}$ indicated 19 carbons and, together with an accurate mass spectra measurement (LREIMS: 296.2571), indicated the molecular formula $\mathrm{C}_{19} \mathrm{H}_{36} \mathrm{O}_{2}$ with two sites of unsaturation for $\underline{5}$. The ${ }^{13} \mathrm{C}$ NMR decoupled spectrum of $\underline{4}$ showed well resolved resonances for all 19 carbons. ${ }^{13} \mathrm{C}$ DEPT analysis using a rotation angle of $90^{\circ}$ indicated one $\mathrm{sp}^{2}$ methine carbon at $\delta 137.0$ and five saturated methines at $\delta 81.2 ; 48.8 ; 30.1 ; 29.7 ;$ and $\delta 28.6$. The DEPT $135^{\circ}$ spectrum showed four methylene $(\delta$ 45.8; 45.4; 36.8 and 29.7$)$ and seven methyl carbons $(\delta 22.1 ; 20.5 ; 20.0 ; 14.6 ; 11.6$; $11.1 ; 7.9$ ) indicating, after comparison with the decoupled spectrum, that the carbons at $\delta 216.3$ and 133.2 were non-hydrogenated.

The ${ }^{1} \mathrm{H}$ NMR spectrum (see table 1 ) of $\underline{5}$ showed signals corresponding to an olefinic proton at $\delta 5.06(1 \mathrm{H}, \mathrm{d}, \mathrm{J}=9.6 \mathrm{~Hz})$, and a singlet at $\delta 1.56(3 \mathrm{H}, \mathrm{s})$ complete the double bond system. A doublet at $\delta 4.03(\mathrm{~d}, 1 \mathrm{H}, \mathrm{J}=9.3 \mathrm{~Hz})$ was attributed to geminal proton on carbon bearing a hydroxyl group. The ${ }^{13} \mathrm{C}$ NMR spectra data also confirmed the existence of one trisubstituted double bond in a linear system: $\delta 137.0(\mathrm{CH}), 133.2(\mathrm{C})$ and $11.1\left(\mathrm{CH}_{3}\right)$ and the existence of a secondary alcohol (C-6) at $\delta 81.2(\mathrm{CH})$. The ${ }^{1} \mathrm{H}$ COSY spectrum showed a correlation between the doublet at $\delta 4.03$ and the signal at $\delta_{\mathrm{H}} 2.70\left(\mathrm{dq}, 1 \mathrm{H}, \mathrm{J}=9.3 ; 6.4 \mathrm{~Hz} ; \delta_{\mathrm{C}} 48.8\right)$ and this one 
Table 1. ${ }^{1} \mathrm{H}$ and ${ }^{13}$ C-NMR Data for Siphonarienolone ${ }^{11}$ and compound 5

\begin{tabular}{|c|c|c|c|c|}
\hline \multirow[b]{2}{*}{ Position } & \multicolumn{2}{|c|}{${ }^{13} \mathrm{C}$} & \multicolumn{2}{|c|}{${ }^{1} \mathrm{H}$} \\
\hline & Siphonarienolone & $\underline{5}$ & Siphonarienolone & $\underline{5}$ \\
\hline 1 & 7.7 & 7.9 & $1.03 \mathrm{t}(7.3)$ & 0.99 t (7.2) \\
\hline 2 & 36.5 & 36.8 & $2.54 \mathrm{~m}$ & $2.48 \mathrm{q}(7.2)$ \\
\hline 3 & 216.0 & 216.3 & - & - \\
\hline 4 & 48.6 & 48.9 & $2.77 \mathrm{dq}(10.17 .2)$ & $2.70 \mathrm{dq}(9.36 .4)$ \\
\hline 5 & 14.3 & 14.6 & $0.90 \mathrm{t}(7.2)$ & $0.86 \mathrm{~d}(6.4)$ \\
\hline 6 & 80.9 & 81.2 & $4.1 \mathrm{~d}(10.1)$ & $4.03 \mathrm{~d}(9.3)$ \\
\hline 7 & 133.7 & 133.2 & - & - \\
\hline 8 & 10.8 & 11.1 & $1.63 \mathrm{~s}$ & $1.56 \mathrm{~s}$ \\
\hline 9 & 136.7 & 137.0 & $5.13 \mathrm{~d}(9.8)$ & $5.06 \mathrm{~d}(9.6)$ \\
\hline 10 & 29.8 & 29.7 & $2.52 \mathrm{~m}$ & $2.48 \mathrm{t}(9.3)$ \\
\hline 11 & 20.4 & 20.5 & $0.92 \mathrm{~d}(6.3)$ & $0.84 \mathrm{~d}(7.4)$ \\
\hline 12 & 46.0 & 45.8 & $1.10 \mathrm{~m}$ & $1.10 \mathrm{~m}$ \\
\hline 13 & 29.8 & 30.1 & $1.54 \mathrm{~m}$ & $1.50 \mathrm{~m}$ \\
\hline 14 & 20.3 & 20.0 & $0.79 \mathrm{~d}(6.5)$ & $0.73 \mathrm{~d}(6.5)$ \\
\hline 15 & 45.1 & 45.4 & $1.38 \mathrm{~m}$ & $1.36 \mathrm{~m}$ \\
\hline 16 & 28.3 & 28.6 & $1.53 \mathrm{~m}$ & $1.50 \mathrm{~m}$ \\
\hline 17 & 21.8 & 22.1 & $0.85 \mathrm{~d}(6.3)$ & $0.74 \mathrm{~d}(6.5)$ \\
\hline 18 & 39.4 & 29.7 & $1.28 \mathrm{~m}$ & $1.25 \mathrm{~m}$ \\
\hline 19 & 20.0 & 11.6 & $1.30 \mathrm{~m}$ & $0.76 \mathrm{t}(5.0)$ \\
\hline 20 & 14.3 & & $0.90 \mathrm{t}(7.2)$ & \\
\hline
\end{tabular}

was connected to a methyl group $\delta_{\mathrm{H}} 0.86\left(\mathrm{q}, 3 \mathrm{H}, \mathrm{J}=6.4 \mathrm{~Hz} ; \delta_{\mathrm{C}}\right.$ 14.6). An ethyl group vicinal to a carbonyl group was deduced by the following signals: a methylene at $\delta_{\mathrm{H}} 2.48\left(\mathrm{q}, 2 \mathrm{H}, \mathrm{J}=7.2 \mathrm{~Hz} ; \delta_{\mathrm{C}}\right.$ 36.8 ) coupled to the methyl group at $\delta_{\mathrm{H}} 0.99\left(\mathrm{q}, 3 \mathrm{H}, \mathrm{J}=7.2 \mathrm{~Hz} ; \delta_{\mathrm{C}}\right.$ 7.9 ) was observed in the ${ }^{1} \mathrm{H}$ COSY spectrum. Four additional methyl groups were observed at $\delta_{\mathrm{H}} 0.84\left(\delta, 3 \mathrm{H}, \mathrm{J}=7.4 \mathrm{~Hz} ; \mathrm{d}_{\mathrm{C}} 20.5\right) ; \delta_{\mathrm{H}}$ $0.73\left(\mathrm{~d}, 3 \mathrm{H}, \mathrm{J}=6.5 \mathrm{~Hz} ; \delta_{\mathrm{C}} 20.0\right) ; \delta_{\mathrm{H}} 0.74\left(\mathrm{~d}, 3 \mathrm{H}, \mathrm{J}=6.5 \mathrm{~Hz} ; \delta_{\mathrm{C}}\right.$ $22.1)$ and $\delta_{\mathrm{H}} 0.76\left(\mathrm{t}, 3 \mathrm{H}, \mathrm{J}=5.0 \mathrm{~Hz} ; \delta_{\mathrm{C}} 14.6\right)$. Finally, the ketone group was defined by ${ }^{13} \mathrm{C}-\mathrm{NMR}$ signal at $\delta 216.3$ (C-3). Other overlapped signals were not assigned. The data shown above together with analysis of ${ }^{1} \mathrm{H}$ COSY, HMQC and HMBC experiments are in agreement with a polypropionate alcohol with 19 carbon atoms instead of 20 which are presents in siphonarienolone ${ }^{11}$. The NMR data of compound $\underline{5}$ are in agreement with those of siphonarienolone (see Table 1) however, there is a difference between the values the optical rotations even its has the same sign (compound $\underline{5}[\alpha]_{24}{ }^{\mathrm{D}}=52.6^{\circ}$ and siphonarienolone $[\alpha]_{24}{ }^{\mathrm{D}}=19.6^{\circ}$ ) The stereochemistry shown in $\underline{5}$ was proposed by analogy with other polypropionates isolated previously from the same mollusk ${ }^{8,9}$ and by the ROESY NMR spectroscopy cross-peak that was found between $\mathrm{H}-4$ and Me-5. No other valuable information from this method was obtained. The same stereochemistry relationship were found in two analogous compounds isolated previously ${ }^{11,12}$ Once again, a norpolypropionate was isolated from $S$. lessoni but in this opportunity $\underline{5}$ was a pure compound instead of a mixture.

\section{EXPERIMENTAL PART}

The ${ }^{1} \mathrm{H}(300 \mathrm{MHz})$ and ${ }^{13} \mathrm{C}(75.5 \mathrm{MHz})$ spectra were recorded on a Bruker AMX-300 spectrometer, chemical shifts are reported relative to $\mathrm{Me}_{4} \mathrm{Si}$ and coupling constants are given in Hertz. Mass spectra were recorded on a V. G. Micromass, ZAB-2R. Infrared spectra were measured on a Bruker IFS-25 spectrometer. Optical rotation was determined for solution in $\mathrm{CHCl}_{3}$ with a Perkin-Elmer Mod. 241 polarimeter. Silica gel chromatography was performed on silica gel Merck $\mathrm{N}^{\circ} 7734$ and 7741.The tlc plates were developed by spraying with $\mathrm{H}_{2} \mathrm{SO}_{4}-\mathrm{H}_{2} \mathrm{O}-\mathrm{AcOH}(1: 4: 20)$ and heating. Sephadex LH-20 obtained from Pharmacia was used for gel filtration chromatography.

\section{Collection and extraction of Siphonaria lessoni}

650 specimens of $S$. lessoni were collected from the intertidal zone at Las Cruces, V Región and stored in acetone until work up. The extract was decanted and the specimens were re-extracted with acetone. The acetone extracts were pooled, concentrated and partitioned between EtOAc and water. The polypropionate compounds obtained from the concentrated EtOAc partition layer by silica chromatography EtOAc / $n$-hexane (1:2), normal HPLC EtOAc/ $n$-hexane (1:4) phase were compound $\underline{3}$ and $\underline{4}$. Polar fractions of the chromatography were rechromatographed on $\mathrm{SiO}_{2}$, obtaining a oil. The oil was filtered through a silica gel using EtOAc/n-hexane (3:1) as eluant to obtain the compound $\underline{5}$.

Compound $\underline{5}$.- oil $[\alpha]_{24}{ }^{\mathrm{D}}=52.6^{\circ}\left(\mathrm{c} 0,076 \mathrm{~g} / 100 \mathrm{~mL} \mathrm{CHCl}_{3}\right) \mathrm{IR}$ $\mathrm{KBr} v_{\max }^{\mathrm{CCl} 4} \mathrm{~cm}^{-1}: 3460,2980,2900,1700,1450,1370,1000,970$, 860. MS: m/z (\%) $296\left(\mathrm{C}_{19} \mathrm{H}_{36} \mathrm{O}_{2}\right), 279$ (2), 221 (1), 211 (3), 155 (12), 141 (1), 137 (4), 115 (4), 97 (12), 57 (100). NMR spectral data: ${ }^{1} \mathrm{H}$ NMR $\left(\mathrm{CDCl}_{3}\right.$, ) and ${ }^{13} \mathrm{C}-\mathrm{NMR}$ : see Table 1.

\section{ACKNOWLEDGEMENTS}

The research was supported by grants from DID (Universidad de Chile) and Fondecyt No 1040651.

\section{REFERENCES}

1. De Villiers, C. J.; Hodgson, A. N.; Proceedings of the Electron Microscopy Society of Southern Africa 1984, 14, 93.

2. Davies - Coleman, M. T.; Garson, M. J.; Nat. Prod. Rep. 1998, 15, 477.

3. Garson, M. J.; Jones, D. D.; Small, C. J.; Liang, J.; Clardy, J.; Tetrahedron Lett. 1994, 35, 6921.

4. Hochlowski, J. E.; Faulkner, D. J. ; Tetrahedron Lett. 1983, 24, 1917.

5. Hochlowski, J. E.; Faulkner, D. J.; Matsumoto, G. K.; Clardy, J.; J. Am. Chem. Soc. 1983, 105, 7413.

6. Manker, D. C.; Garson, M. J.; Faulkner, D. J.; J. Chem. Soc. Chem. Commun. 1988, 16, 1061.

7. Paterson, J.; Perkins, M. V.; Tetrahedron Lett. 1992, 33, 801.

8. Rovirosa, J.; Quezada, E.; San-Martín, A.; Bol. Soc. Chil. Quím. 1991, 36, 233.

9. Capon, R. J.; Faulkner, D. J.; J. Org. Chem. 1984, 49, 2506.

10. Norte, M.; Cataldo, F.; Gonzalez, A.; Tetrahedron Lett. 1988, 29, 2879.

11. Norte, M.; Cataldo, F.; González, A. G.; Rodríguez, M. L.; Ruiz-Pérez, C.; Tetrahedron 1990, 46, 1669.

12. Hochlowski, J. E.; Faulkner D. J.; J. Org. Chem. 1984, 49, 3838. 